\title{
Posterior urethral valve presenting with impacted prostatic urethral calculus: a diagnostic challenge
}

\author{
Ashish Sharma, Gaurav Garg, Rahul Janak Sinha, Vishwajeet Singh
}

Department of Urology, King George's Medical University, Lucknow, Uttar-Pradesh, India

Correspondence to Dr Rahul Janak Sinha, rahuljanaksinha@rediffmail. com,

rahuljanaksinha@rediffmail.com

Accepted 29 August 2018

\section{DESCRIPTION}

A 5-year-old boy presented with complaints of difficulty in micturition for the last 3 days and acute urinary retention for 1 day. History revealed symptom of occasionally crying during voiding since birth for which no medical advice was taken in the past. There was no history of any lithuria, haematuria or recurrent episodes of fever. The general physical examination was unremarkable. The routine blood investigations and urine culture were also normal. Urine routine microscopy showed $4-5$ pus cells/HPF. Ultrasonography of the abdomen revealed thickening of the bladder wall with normal upper tracts. Further evaluation with X-ray pelvis and voiding cystourethrogram (VCUG) showed a radiopaque shadow in the prostatic urethra along with dilated posterior urethra as shown in figure 1 . The patient was subsequently taken for cystopanendoscopy which revealed posterior urethral valve type one along with a dilated posterior urethra as shown in figure 2. An impacted calculus measuring approximately $10 \mathrm{~mm}$ was noted just proximal to PUV and it was pushed back into the bladder. Intraoperatively, the patient's relative was informed for presence of associated PUV and consent was taken for fulguration. The intracorporeal lithotripsy for calculus with fulguration of the PUV was performed using holmium:YAG laser. The complete stone clearance was achieved. The postoperative period was uneventful and the patient was discharged after Foley catheter removal on postoperative day 5. On 3-month follow-up, he was voiding well with insignificant postvoid residual urine and normal upper tracts.

Posterior urethral valve is a common cause of urinary tract obstruction in male neonates and children. A urethral calculus in children is a rare entity, and its association with PUV is still rarer with only a handful of reported cases in literature. ${ }^{12}$ In males, the the most common location of urethral calculi is the posterior urethra and the associated PUV

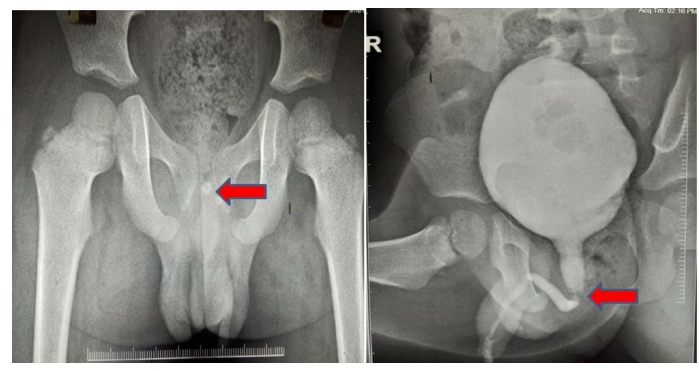

Figure 1 Plain X-ray pelvis and voiding cystourethrogram showing a radiopaque shadow in the prostatic urethra along with dilated posterior urethra.

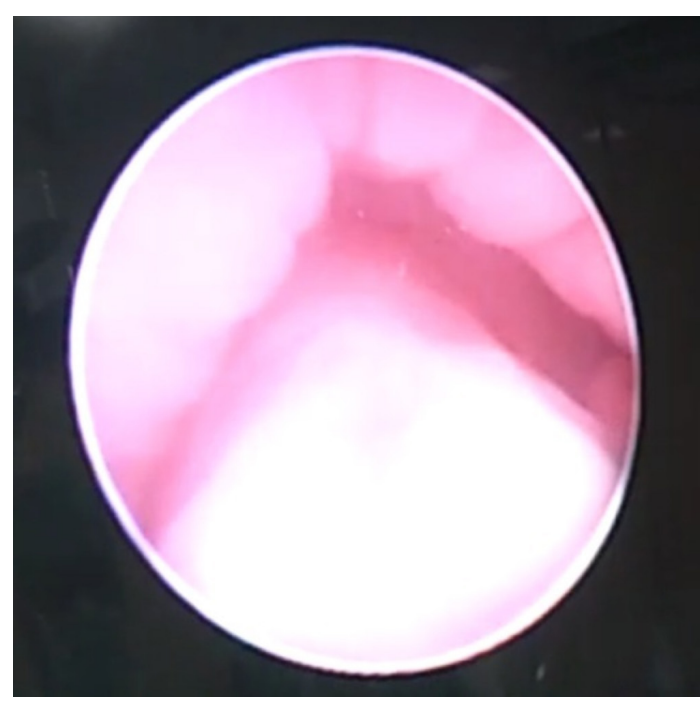

Figure 2 Intraoperative cystopanendoscopy showing posterior urethral valve type 1 .

may be the site of impaction. The urethral calculus may present with haematuria, acute urinary retention and dysuria. These symptoms can overlap with PUV, and it may be difficult to diagnose on radiological imaging whether symptoms are due to PUV or calculus. Plain X-ray KUB and VCUG are required during evaluation, but the VCUG can be inconclusive to figure out whether the dilatation is due to PUV or the impacted calculus. ${ }^{2}{ }^{3}$ Cystourethroscopy is the most definitive diagnostic and therapeutic modality for these clinical entities alone or together. Fulguration should be followed by lithotripsy (ie, after dealing with the obstructing urethral valve) so as the stone fragments are removed easily during washes. The determining factors for selecting

\section{Learning points}

- The urethral calculus and the PUV may rarely present together and usually have similar clinical presentations, especially in cases of PUV that present later in life.

- The posterior urethral valve may be rarely a predisposing factor for calculus impaction.

- It is axiomatic to keep these two conflicting conditions in mind when evaluating a child with lower urinary tract symptoms.

- Radiological imaging may not be conclusive for diagnosing the PUV in the presence of urethral calculus and cystopanendoscopy is required for definitive diagnosis and treatment. 
the preferred modality for these stone fragments among extracorporeal shock wave lithotripsy, transurethral cystolithotripsy, percutaneous cystolitholapaxy and open cystolithotmy are stone size, age of patient, stone composition, status of urethra, accompanying disease, treatment cost and surgeon's preference. ${ }^{34}$ In adult patients, $<7 \mathrm{~mm}$ stone can be easily retrieved without the need of lithotripsy through cystoscopic sheath with or without stone removal system assistance. ${ }^{4}$ However, children have narrow urethra, so stone size threshold for lithotripsy should be kept at lower side. The high index of suspicion must be borne in mind for diagnosing these two clinical conditions together. ${ }^{5}$

Contributors AS: concept, design, supervision, processing, writing manuscript and critical analysis. GG: concept, design, supervision, processing, writing manuscript and critical analysis. RJS: supervision, processing, writing manuscript and critical analysis. VS: concept, supervision, writing manuscript and critical analysis.
Funding The authors have not declared a specific grant for this research from any funding agency in the public, commercial or not-for-profit sectors.

Competing interests None declared.

Patient consent Guardian consent obtained.

Provenance and peer review Not commissioned; externally peer reviewed.

\section{REFERENCES}

1 Neulander E, Kaneti J. Posterior urethral valves and vesicolithiasis in children. Int Urol Nephrol 1996;28:563-8.

2 Mallouh C. Urethral valves: unusual presentation in 14-year-old boy. Int Urol Nephrol 1993:25:235-7.

3 Torricelli FC, Mazzucchi E, Danilovic A, et al. Surgical management of bladder stones: literature review. Rev Col Bras Cir 2013;40:227-33.

4 Li A, Ji C, Wang H, et al. Transurethral cystolitholapaxy with the AH-1 stone removal system for the treatment of bladder stones of variable size. BMC Urol 2015;15:9.

5 Sinha A, Sarin YK, Sengar M. Posterior urethral valves associated with urethral calculi. Indian J Urol 2001;18:84-5.

Copyright 2018 BMJ Publishing Group. All rights reserved. For permission to reuse any of this content visit

http://group.bmj.com/group/rights-licensing/permissions.

BMJ Case Report Fellows may re-use this article for personal use and teaching without any further permission.

Become a Fellow of BMJ Case Reports today and you can:

- Submit as many cases as you like

- Enjoy fast sympathetic peer review and rapid publication of accepted articles

- Access all the published articles

Re-use any of the published material for personal use and teaching without further permission

For information on Institutional Fellowships contact consortiasales@bmjgroup.com

Visit casereports.bmj.com for more articles like this and to become a Fellow 